\title{
Law and the Imagination in Medieval Wales
}


THE MIDDLE AGES SERIES

\section{Ruth Mazo Karras, Series Editor \\ Edward Peters, Founding Editor}

A complete list of books in the series is available from the publisher. 


\title{
Law and the Imagination in Medieval Wales
}

\author{
Robin Chapman Stacey
}

\author{
$\overline{\text { PENN }}$ \\ UNIVERSITY OF PENNSYLVANIA PRESS \\ PHILA DELPHIA
}


Copyright (C) 2018 University of Pennsylvania Press

All rights reserved. Except for brief quotations used for purposes of review or scholarly citation, none of this book may be reproduced in any form by any means without written permission from the publisher.

$$
\begin{gathered}
\text { Published by } \\
\text { University of Pennsylvania Press } \\
\text { Philadelphia, Pennsylvania I9IO4-4II2 } \\
\text { www.upenn.edu/pennpress }
\end{gathered}
$$

Printed in the United States of America on acid-free paper

$$
\text { I } 3579 \text { IO } 8642
$$

Library of Congress Cataloging-in-Publication Data Names: Stacey, Robin Chapman, author.

Title: Law and the imagination in medieval Wales / Robin Chapman Stacey.

Other titles: Middle Ages series.

Description: Ist edition. | Philadelphia : University of Pennsylvania Press, [2018] | Series: Middle Ages series | Includes bibliographical references and index.

Identifiers: LCCN 2018008684 | ISBN 97808122505IO (hardcover : alk. paper)

Subjects: LCSH: Law-Wales_-History. | Law, Medieval. | Law and literature-Wales-History. | Culture and lawWales-History. | Imagination-Political aspects-WalesHistory.

Classification: LCC KD9430 .S73 2018 | DDC $349.42909 / 02-\mathrm{dc} 23$

LC record available at https://lccn.loc.gov/20I80o8684 
For my much-loved son Will (1988-2012),

and all that he was, and for his remarkable sister Anna and great love Kimmy, who have found the courage to embrace the world in all its sharp beauty and sadness 
This page intentionally left blank 